\title{
Vulnerability of People Suffering from Sickle Cell Disease
}

\author{
Vulnerabilidade de pessoas que sofrem com anemia falciforme
}

\author{
Liliany Santana da Silva ${ }^{1}$; Cláudia Cecília Blaszkowski de Jacobi²; \\ Larissa Rolim Borges-Paluch ${ }^{3 *}$
}
${ }^{1}$ Faculdade Maria Milza - FAMAM, BR-101, Governador Mangabeira - BA, Brasil, 44350- 000, lilaros2@gmail.com

${ }^{2}$ Faculdade Maria Milza - FAMAM, Programa de Pós-Graduação em Desenvolvimento Regional e Meio Ambiente, BR-101, Governador Mangabeira - BA, Brasil, 44350-000, cbjacobi@gmail.com
${ }^{3 *}$ Faculdade Maria Milza - FAMAM, Programa de Pós-Graduação em Desenvolvimento Regional e Meio Ambiente, BR-101, Governador Mangabeira - BA, Brasil, 44350-000, larissapaluch@gmail.com ORCID: https://orcid.org/0000-0002-1810-0902

\begin{abstract}
The aim of this study, which is a qualitative research carried out in Family Health Units of two Recôncavo municipalities, is to assess social, individual and programmatic vulnerabilities of people with sickle cell disease. Data were obtained by means of forms and interviews whose contents were thematically analyzed. Based on 26 interviews we observed that social vulnerability is higher among black, low-income women; individual vulnerability depends on the knowledge-about-the-disease variable; and programmatic vulnerability is influenced by access to and use of health services. From our data we might conclude that vulnerabilities could be reduced offering more information about the disease, especially on immunization practices, drugs and follow-ups. In our opinion, it is important to create sickle cell patient associations where people can share experiences, difficulties and thoughts in order to find solutions to problems and foster the development of regional and national policies.
\end{abstract}

Keywords: Hemoglobin SC Disease, population, health vulnerability.

\section{Resumo}

O presente estudo objetivou investigar as vulnerabilidades social, individual e programática em indivíduos com doença falciforme. Pesquisa qualitativa realizada nas unidades de saúde da família em dois municípios do Recôncavo Baiano. Os dados foram obtidos através da aplicação de formulários e entrevista e submetidos à análise de conteúdo temática. Com base nas entrevistas realizadas em 26 indivíduos com doença falciforme verificou-se que a vulnerabilidade social é maior em pessoas do sexo feminino, raça negra, baixa renda e ocupação informal. A vulnerabilidade individual é influenciada principalmente pela variável conhecimento sobre a doença. Quanto à vulnerabilidade programática, as variáveis que melhor 
explicaram a variabilidade dos dados foram o acesso e uso de serviços de saúde. Fundamentado nos resultados obtidos, acredita-se que a minimização das vulnerabilidades pode ser obtida com o acesso às informações sobre a doença, principalmente a imunização, medicamento e acompanhamento na atenção primária. Conclui-se que, é importante incentivar a criação de associações de pessoas com a doença, para troca de experiências, dificuldades e reflexão compartilhada visando à busca de soluções dos problemas e criação de políticas regionais e nacionais.

Palavras-chave: Doença da Hemoglobina SC, população, vulnerabilidade em saúde.

\section{Introduction}

Sickle cell disease (SCD) is a pathology caused by hemoglobin genetic modifications which turn the red blood cells abnormally sickle-shaped. Being a genetically transmitted disorder, it deserves special attention from health professionals with regard to reception, qualified care, and early and correct diagnosis in order to minimize vulnerabilities and ensure life quality (BRASIL, 2009). SCD is the most frequent monogenic pathology in Brazil and affects mainly AfroBrazilians (BRASIL, 2014). The recognition of its prevalence was decisive in the establishment of the National Policy for Comprehensive Care for People with Sickle Cell Disease (PNAIPDF) (BRASIL 2017). Approximately 4\% of the Brazilian population has the sickle cell trait (simple heterozygosis) and that 25.000 to 50.000 people have a disease in a homozygous state or in the condition of compound or double heterozygotes, with an estimate of 25.000 to 30.000 cases (BRASIL, 2018).

These genetic hemoglobin changes cause intense pain, ischemia, necrosis, dysfunctions, tissue and organ irreversible damage, and chronic anemia. These painful consequences of the disorder affect the patient's life and increase his/her vulnerabilities. Nowadays vulnerability is understood as dynamic, transdisciplinary and qualitative encompassing three dimensions: individual, social and programmatic (Cordeiro et al., 2014).

Individual vulnerability refers to the amount and quality of information available to each person; individual vulnerability comprises the set of social factors that determine the access not only to information, services and cultural goods, but also the constraints to the exercise of citizenship, violence, political priority and investment in health services and housing, education and work. Programmatic vulnerability is related to the authorities' actions to reduce the 
occurrence of diseases (Berardinelli et al., 2010).

Thus, the aim of this study is to assess the social, individual and programmatic vulnerabilities of people with SCD. Due to the lack of research on this subject in the Recôncavo Baiano, our results might shed some light on decision-making regarding resource management, health professional training and public policies.

\section{Material \& Methods}

A descriptive qualitative research was carried out in two municipalities of the Recôncavo Baiano: Sapeaçú and Cruz das Almas. Twenty-six adult SCD patients were selected from Family Health Units (FHU), according to the following inclusion criteria: > 18 years old, confirmed diagnosis, being registered in a FHU and agreeing to participate in the research.

Data were collected in the FHUs from May to August 2015, after scheduling an appointment with the responsible nurse and the community health workers to explain the objective and the relevance of the research.

The decision of conducting interviews as a technique to gather information was taken for two main reasons. The first one is related to the difficulties people might have to understand the questions posed in a questionnaire, and the second was determined by the researchers' interest in getting to know as deep as possible the reality and needs of each individual. The answers were fully registered and care was taken not to induce any answers. Data were collected by means of a form created to assess and evaluate the population vulnerability and was composed of closed and open questions regarding their variables. The project was approved by the Ethics Committee of Faculdade Maria Milza (CEP-FAMAM 1.024.849) and is in accordance with resolution 466/12 of the National Health Council.

Data were organized in tables to characterize social, individual and programmatic vulnerabilities and a qualitative evaluation was carried out by means of a content analysis.

\section{Results}

As shown in Table 1, the age of patients with sickle cell disease varied between 18 and 50 years; $46 \%$ were in the 18-29 age bracket, and $69.2 \%$ were women. With regard to 
marital status, $53.8 \%$ were married or in stable unions, and $46.2 \%$ were single. In terms of color/race, $57.7 \%$ of the individuals defined themselves as black and $42.43 \%$ as mulattos. When analyzing occupation data a wide variation of jobs was observed, although most of the individuals were housewives (46\%) who took care of the house and the family without contributing to social security. Other occupations included farmers (15\%) and unemployed individuals (15\%). When asked about the family income, $42.5 \%$ of the patients answered, they received less than the statutory minimum wage and $38.4 \%$ received the statutory minimum wage. People with higher income (more than the statutory minimum wage) were either married or receiving government aid. Forty six percent of the interviewed individuals stated they did not receive government aid, 27\% were enrolled in the Family Aid Program, $23 \%$ received disability insurance, and $4 \%$ received both benefits. Most of the individuals had a high school degree (42.4\%) or did not finish elementary school $(27 \%)$. With regard to religion, just two were mentioned, catholic (69.2\%) or evangelical $(30.8 \%)$.

Table 1. Social vulnerability variables of people with SCD in municipalities of the Recôncavo da Bahia, Brazil, 2015.

\begin{tabular}{llll}
\hline SOCIAL VULNERABILITY VARIABLES & N & \% \\
\hline \multicolumn{2}{c}{ Age group } & 12 & 46.0 \\
$18-29$ & 06 & 23.0 \\
$30-39$ & 08 & 31.0 \\
$40-55 \quad$ Gender & 18 & \\
Female & 08 & 69.2 \\
Male & & 30.8 \\
Marital status & 14 & \\
Married* & 12 & 53.8 \\
Single & & 46.2 \\
Race/color & 11 & \\
Mulatto & 15 & 42.3 \\
Black & & 57.7 \\
Occupation & 12 & 46 \\
Housewife & 04 & 15 \\
Unemployed & 04 & 15 \\
Farmer & 06 & 16 \\
Others occupation** & & \\
Family income & &
\end{tabular}




\begin{tabular}{lll}
\hline < 01 minimum wage & 11 & 42.5 \\
01 minimum wage & 10 & 38.4 \\
01 to 2 minimum wages & 01 & 03.8 \\
02 to 4 minimum wages & 02 & 07.7 \\
No income or no answer & 02 & 07,6 \\
$\quad$ Social benefits & & 46.0 \\
No $\quad 12$ & 27.0 \\
Yes/Family Aid & 07 & 23.0 \\
Yes/disability insurance & 06 & 04.0 \\
Both beneficts*** & 01 & 11.5 \\
$\quad$ Schooling & & 27.0 \\
Elementary School & 03 & 42.4 \\
Unfinished Elementary School & 07 & 15.3 \\
High School Degree & 11 & 03.8 \\
Unfinished High School & 04 & 69.2 \\
Unfinished college & 01 & 30.8 \\
Religion & & \\
Evatholic & 18 & \\
\hline
\end{tabular}

Source: research data. Legend: * Married or common-law marriage *Others occupation: General services, Craftsperson, Day labourer, Machine assistant, Independent trader ${ }^{* *}$ Family Aid and disability insurance

In terms of individual vulnerability (Table 2), 69.2\% of the interviewed individuals stated their partners did not suffer from SCD nor carried the trait; $30.8 \%$ either did not know because they were single or would rather not answer the question. From the 26 interviewed individuals $57.7 \%$ had children and $58 \%$ of them inherited traits of the disease. When asked about their knowledge about the disease, $57.7 \%$ said they knew, and with regard to medication to relieve the symptoms, $23.1 \%$ said they did not take any medication and $19.2 \%$ took folic acid.

Table 2. Individual vulnerability variables of people with SCD in municipalities of the Recôncavo da Bahia, Brazil, 2015.

\begin{tabular}{|c|c|c|}
\hline INDIVIDUAL VULNERABILITY VARIABLES & $\mathbf{N}$ & $\%$ \\
\hline \multicolumn{3}{|c|}{ The partner has sickle cell disease } \\
\hline No & 18 & 69.2 \\
\hline No answer & 08 & 30.8 \\
\hline \multicolumn{3}{|l|}{ Children } \\
\hline Yes & 15 & 57.7 \\
\hline No & 11 & 42.3 \\
\hline \multicolumn{3}{|c|}{ The offspring has SCD or trait } \\
\hline
\end{tabular}




\begin{tabular}{lcc}
\hline Yes. Trait & 15 & 58 \\
Does not apply & 11 & 42 \\
& Knowledge about SCD & \\
& 15 & 57.7 \\
Yes & 11 & 42.3 \\
No & Does the patient know about the SCD treatment \\
\multicolumn{1}{c}{} \\
No & 06 & 23.1 \\
Folic acid & 05 & 19.2 \\
Hydration and folic acid & 04 & 15.4 \\
Avoid iron-rich food & 02 & 07.7 \\
Folic acid ando olher ${ }^{1 *}$ & 02 & 07.7 \\
Folic acid ando other ${ }^{2 * *}$ & 02 & 07.7 \\
Folic acid and other ${ }^{3 * * *}$ & 01 & 03.8 \\
Folic acid and/or nimesulide & 01 & 03.8 \\
Diet, adequate medicine use & 01 & 03.8 \\
Folic acid and vitamin B $_{3}$ & 01 & 03.8 \\
Folic acid and ibuprophene & 01 & 03.8 \\
\hline
\end{tabular}

Source: research data. Legend: "Folic acid and other1: nimesulide, ibuprophene and/or dipyrone ${ }^{* *}$ Folic acid and other 2: diclophenac and/or ibuprophene; ${ }^{* * *}$ Folic acid and other 3: hydroxyurea, diclophenac and/or paracetamol

The programmatic vulnerability analysis (Table 3 ) revealed that $61.5 \%$ did not have access to medication, $34.6 \%$ got the medication at the FHU and $3.8 \%$ at the Hematological and Hemotherapy Foundation of the State of Bahia (HEMOBA).

Fifty percent of the interviewees stated they did not have access to any kind of vaccines. When asked if they, as SCD patients, were registered at the Municipal Department of Health, $84.6 \%$ said the Department was informed of the diagnosis through the health workers or because they had asked for transportation to be treated in a different municipality.

According to the data collected, $57.7 \%$ of the patients did not receive information on the aftereffects and complications of the disease at the FHU. The only information they reported getting was the day of the next medical appointment or of a lecture on some disease, not necessarily SCD. 
Table 3. Programmatic vulnerability variables of people with SCD in municipalities of the Recôncavo da Bahia, Brazil, 2015.

\begin{tabular}{|c|c|c|}
\hline PROGRAMMATIC VULNERABILITY VARIABLES & $\mathbf{N}$ & $\%$ \\
\hline \multicolumn{3}{|l|}{ Have access to SCD medication } \\
\hline No & 16 & 61.5 \\
\hline Yes/FHU & 09 & 34.6 \\
\hline Yes/ HEMOBA & 01 & 03.8 \\
\hline \multicolumn{3}{|l|}{ Receive special vaccines at FHS* } \\
\hline No & 13 & 50.0 \\
\hline Yes & 13 & 50.0 \\
\hline \multicolumn{3}{|l|}{ The patient is registered at the MDH** } \\
\hline No & 04 & 15.4 \\
\hline Yes & 22 & 84.6 \\
\hline \multicolumn{3}{|l|}{ Your FHP** offers some kind of information } \\
\hline No & 15 & 57.7 \\
\hline Yes & 11 & 42.3 \\
\hline \multicolumn{3}{|l|}{ Treatment is outside the municipality } \\
\hline No & 08 & 30.8 \\
\hline Yes & 18 & 69.2 \\
\hline \multicolumn{3}{|l|}{ Who pays for the transportation } \\
\hline Pacient & 09 & 50.0 \\
\hline Family or Health Department & 09 & 50.0 \\
\hline
\end{tabular}

Source: research data. Legend: ${ }^{*}$ FHS: Family Health Strategy, ${ }^{* *} \mathrm{MDH}$ : Municipal Department of Health, ${ }^{* * *}$ FHP: Family Health Program - offers some kind of information due to the diagnosis

From the 26 interviewed individuals, $69.2 \%$ were treated in a municipality different to the one they lived in. One-half of the patients paid for their own transportation and the other half was paid by the Municipal Department of Health or by relatives.

\section{Discussion}

In order to plan effective local, national and international actions that improve the life quality of patients, the SCD patients' vulnerabilities must be understood. With regard to social vulnerability, the majority of patients is composed of young adults. Similar results were reported by Roberti et al. (2010) in a study carried out with 60 SCD patients treated in the Hospital das Clínicas of the Universidade Federal de Goiás. In their research, $66.7 \%$ of the individuals were in the 14-30 age bracket, while only 8.3\% were between 46 and 60 years old.

Ferreira et al. (2013) assessed the SCD vulnerability of 12 adults and observed that most 
individuals were between 29 and 39 years old. According to the authors, the small sample in the research was due to early mortality, as reported by community workers and relatives in the study areas. In their study of the social and epidemiologic aspects of SCD Félix, Sousa \& Ribeiro (2010) also observed that $57.4 \%$ of the patients were young adults between 18 and 30 years old. However, the authors reported a $40 \%$ reduction in early mortality probably due to neonatal diagnosis, vaccines, prophylactic antibiotic therapy and introduction of hydroxyurea.

The higher number of women with SCD found in our study when compared to men might be related to the fact that women seek more health care services than men and thus are easier to diagnose. Our results are in accordance with those of Pitaluga (2006), who found that $61.6 \%$ of the participants in his research were women. Félix et al. (2010) also found a higher number of women $(59.6 \%)$ than men $(40.4 \%)$. França (2015), on the other hand, studied SCD patients in a blood center and did not find significant differences between women and men (49\% and 51\%, respectively).

Although in our research $69.2 \%$ of the patients were women, there are no studies that substantiate the prevalence of women among SCD patients, since the globin chain that originates the HbS hemoglobin is not defined by sex (Zago \& Pinto, 2007). Most of the interviewees in our study were married or in common-law marriages, and they stated that the partner's support made it easier to cope with the disease.

In Pitaluga's (2006) study, however, 53.3\% of the patients were single. According to the author this condition suggests social support frailty which might enhance the internal conflicts caused by the disease as well as anxiety, discrimination and isolation.

On the other hand, in Amaral's et al. (2015) study on the sociodemographic, economic and health profile of adults with SCD, $50 \%$ of the patients in their sample lived with a partner. The authors claimed that single women are socially more vulnerable than married ones. França (2015) states that the absence of a husband or partner in families where there are people suffering from SCD increases the weakness and fragility of family bonds which characterize vulnerable families.

When asked about race or color, all the interviewees declared themselves black or mulattos, which is in accordance with information from the Ministry of Health that states that SCD affects 
mainly the Afro-Brazilian population, considering their internal diversity in terms of age, genre and socio-economic situation (BRASIL, 2009; 2014). The racial question is also relevant, since it contributes to the increase of social vulnerability, reducing protection opportunities against the disease and adding to the inequities in the health area.

Brignol et al. (2015) found that the geographic distribution of people with SCD in Bahia is heterogeneous, but their number seems to be higher in the Recôncavo Baiano, São Francisco and coastal areas. With regard to SCD in adults, Ferreira et al. (2013) carried out a research in a municipality of Bahia where they found hegemony of self-declared black people. For the authors chronic diseases and poverty enhance the race/color vulnerability.

A similar research was carried out by Félix, et al. (2010) in Minas Gerais with SCD patients, and they found $78.7 \%$ and $17 \%$ of self-declared black and mulattos, respectively. According to França (2015), despite the strong genetic mixing, SCD is still a racial disease affecting more Afro-descendants than white people. Researchers report that skin color is a social marker that affects the vulnerability of certain groups with regard to health problems, including alcoholism, drugs, violence and discrimination (Chor \& Lima, 2005).

In terms of occupation, most of the interviewees had low-paid jobs, which result in low economic stability and reduced social prestige. Most of the women were housewives, as should be expected, since housework and childcare have historically been women's responsibility.

Ferreira et al. (2013) stated that low-paid shops could be related to recurrent pain crisis that would affect school attendance that in its turn would result in the SCD patient's poor development of abilities normally requested in better-paid jobs. According to the authors, socio economic distress, the difficulties of getting a formal job and the impossibility of keeping it due to the health complications caused by the pathology worsen the picture still more.

Approximately $50 \%$ of the interviewees received one minimum statutory wage. SCD patients who received more than 01 minimum wage either were married or received financial support from the government. We believe that in the present case low income is not a consequence of poor schooling, since $42.4 \%$ of the people in our sample finished high school, but could be explained by the absenteeism resulting from pain crisis.

Felix et al. (2010) also found that $48.9 \%$ of the sampled population received one minimum 
statutory wage or less, while $19.1 \%$ did not have any income. In their study, the patients' schooling varied from elementary school to unfinished college. According to the authors low income, poor schooling, lack of a fix salary and job instability contribute to increase vulnerability that leads to low pay or unemployment in adult life.

Silva et al. (2013) emphasized that low income resulted from the lack of qualification of the SCD population, who cannot compete for a position in the job market in order to improve their life quality. However, when they get a job, their absenteeism is high due to the frequent pain crisis. Although the majority of the interviewees said they did not receive government benefits, those benefits are guaranteed by the 1988 Federal Constitution, and the government is obliged to pay a minimum wage per month to people with disabilities. However, SCD patients general give up after the first attempt of obtaining the benefit as a consequence of the bureaucracy and the pain crisis, thus contributing to increase social vulnerability.

Silva \& Silva (2013) reported that most SCD patients lived in a situation of social vulnerability; $40 \%$ of the families received 01 minimum wage and $5 \%$ of them were enrolled in the Family Aid Governmental Project, mainly those who did not receive illness aid. Governmental aid is granted to all insured workers in case of illness or accident if they cannot work for a period longer than 15 consecutive days. In relation to Family Aid, the benefit is granted to families with the appropriate profile regardless of sickness or disability of one or more of their members. The bill $n^{\circ} 389$ of 2012 modifies Law n 8.742 of 1993, which rules over the Social Assistance organization and provides that a minimum wage is granted monthly to anyone suffering from a hereditary disease associated to racial factors.

With regard to education, the majority of the interviewees in the present study finished high school. Similar results were obtained by Félix et al., (2010) who found that $42.5 \%$ of the patients finished high school or had a' university degree. However, in França's (2015) study, carried out in the Blood Center of Bahia (HEMOBA), $76 \%$ of the interviewees finished just elementary school. According to the author, low schooling results in job instability, which contributes to increase the social vulnerability of SCD patients. On the other hand, individuals that finished high school tend to be better informed and more aware of their rights and thus seek access to health services, ask for vaccines and medication, and know that as individuals and social beings 
they are responsible for their own health.

All the participants professed a religion, which played an important role in their lives, for it gave them strength to face the illness. Santos, et al. (2004) state that religion helps to understand, intervene and control the present and the future. In addition, who claim that religion, mainly in the case of vulnerable people, offers comfort as well as individual and familiar support. According to Cordeiro et al. (2014) spirituality and religiosity represent an important social support and wellbeing, where patients may find strength to face their health problems. The health system also urges individuals to seek alternatives to help restore their wellbeing.

With regard to individual vulnerability, our data indicate that most patients suffer from scarceness of information about the SCD, the limitations it imposes on them, their rights, selfcare, and continuous education programs. Moreover, ignorance about the genetic inheritance and the lack of orientation on family planning might increase social vulnerability.

When asked about the knowledge they had concerning the trait or disease inheritance, $69 \%$ of the interviewees stated that the partner did not have the trait or the disease. Since SCD is a genetic disorder, it is mandatory that the patient (heterozygous or homozygous) knows how it is inherited and if the partner has the disease or the trait. Thus, genetic counseling is of the utmost importance to guide carriers towards the understanding of aspects of the disease such as suffering, treatment, prognosis, and making the right decisions in terms of fecundity. Guimarães \& Coelho (2010) emphasize the importance of sexual-affective relationships to transform the above mentioned knowledge into prevention practices.

Since most of the parents find out they are carriers after the result of the Guthrie test, family planning should discuss the genetic inheritance of the disease, health education and the implications of the SCD trait. Due to the scarce knowledge of the interviewees about the disease in our study, it is necessary that the FHUs put on lectures on the subject and conduct active searches to identify the SCD population in order to give them orientation and support.

Seventy seven percent of the interviewees stated they suffered from some sort of pain that is one of the most frequent symptoms of the disease. This specific symptom limits the patient's daily and working activities. As the morbi-mortality rate is directly related to the symptoms, the sooner the crisis awareness and evaluation is carried out, the lower the rate will be. 
Our results are in agreement with those obtained by Martins et al. (2010) who reported that the pain crisis with or without fever that affected $77 \%$ of the interviewees, represented $64.4 \%$ of out-patient care and $36.7 \%$ of the admissions. The most common clinical manifestations were hemoglobin vascular occlusion, followed by tissue and organ infarction, and chronic hemolysis. Pain is considered a subjective symptom as well as a complicating factor in SCD treatment, as has been proved by the correlation found between persistent pain and sudden death. According to Silva et al. (2013), pain is the recurrent symptom of SCD and the most bothersome for it limits working activities as well as social, affective, sexual and family relations directly affecting life quality.

Ohara et al. (2012) found that pain is felt mainly in the hips and lower limbs followed by the dorsal and lumbar region and arms. Oakis et al. (2013) reported bone, thorax and abdominal pain, which, if not swiftly treated, might result in a cerebrovascular accident or brain infarctions. This information corroborate the data obtained in our research. The Ministry of Health considers the pain crisis as the first manifestation of SCD and one of the most frequent complications due to the blood occlusion caused by sickling erythrocytes (BRASIL, 2014). Zago \& Pinto (2007) explain that the SCDs clinical manifestations are the result of the presence of abnormal hemoglobin S. A and fetal hemoglobin even in high concentration do not form organized structures inside the erythrocytes.

When paleness, fever, thoracic or abdominal pain, dyspnea, headache, nausea, vomiting, enlarged spleen or behavioral changes are observed, SCD patients should immediately seek health assistance because those symptoms indicate high risk of infection.

Although $68.9 \%$ of the interviewees used medication, the patients' knowledge about its importance, as for example folic acid, is still scarce. Therefore, it is necessary that the Family Health Program Units be suitably prepared to treat and orient SCD patients as well as give informative lectures on the disease, and actively look for people with the pathology in their area of action. In our research, many patients reported being on self-medication due to the access difficulties to health care centers which increases programmatic and institutional vulnerability.

According to Braga (2007) the patient and his/her family must be taught to recognize the symptoms, their origin and the pain intensity in order to administer folic acid daily, use pain 
killers as soon as pain starts, hydrate the patient or take him/her to the hospital, if the problem cannot be solved at home. In our research, several interviewees reported the use of selfmedication as a consequence of the access difficulties to public health services. This lack of equity will affect the programmatic and institutional vulnerability. With regard to programmatic vulnerability, we observed that public policies fail to guarantee SCD patients access to health services that include low and high complexity medicine.

According to Gomes et al. (2014) the access of SCD patients to the health services starts at the FHS which is the front door to the health system and responsible for the follow-up appointments. It is important to explain that folic acid and painkillers should be provided by the Municipality through Primary Health Care. Besides, when needed, patients should be referred to specialized care centers ideally organized in reference and counter reference networks. According to our data there was low adherence to immunization and many interviewees did not even have an immunization certificate. The order for vaccines is placed to the Special Immunobiological Reference Centers (CRIE) at the FHU through the municipality epidemiological surveillance. The individuals who have not been immunized against hepatitis A, haemophilus influenzae, pneumococcal disease and meningococcemia at the proper age should receive them through the above mentioned centers (Frauches et al., 2010).

Jesus (2010) observed mortality reduction when the vaccines of the National Vaccination Program were combined with Haemophilus influenzae, hepatitis B (recombinant) and Streptococcus pneumoniae (polysaccharide and heptavalent) vaccines, associated to penicillin.

The objective of the Comprehensive Health National Program for the Black Population is to ensure the promotion, prevention, care, treatment and recovery from communicable and noncommunicable diseases, including SCD which has high incidence in that segment of the population. Notwithstanding, França (2015) reported that the pathology seemed to be invisible in the health care services resulting in the lack of specific information for professionals and patients. Empowering patients with knowledge of the meaning of care could help them deal with the daily problems that affect people suffering from chronic diseases (Cordeiro et al., 2014).

Our research shows that access difficulties result in poor schooling and scarceness of health information. In addition, we believe that the lack of information is due to the patients' low 
schooling and low socioeconomic level. Moreover, health education and information does not impose adequate behaviors but offers the opportunity to reflect on the dialogical interaction among social subjects.

Information allows patients to understand and prevent the SCD symptoms. Cordeiro, et al. (2014) analyzed SCD patients' speeches and found that winter is considered a threat, because during this season, the symptoms worsen and the pain crisis increase. Ordinance 399 issued by de Health Ministry in February 2006 establishes regional decentralization in order to improve municipalities' and states' access, decision making and quality of health services. The aim of the ordinance is also to reduce social and territorial inequalities, and to offer a comprehensive health care system. The good relation between the patient, his/her family and the health team is relevant to improve the patient's understanding of the disease and his/her attachment to just one reference center (Braga, 2007). In addition, this relation is deeply affected by the health team knowledge of the territory, the culture, the demography and the difficulties to articulate with the health care network in order to improve the patient's quality of life.

Some of the SCD patients require medium complexity treatments that cannot be provided by the municipality they reside in, as is the case with hematologists that mainly work in the capital city of the state. However, the visits to the specialists outside the municipality are difficult due to the cost of transportation that not always can be afforded by the municipality. When transportation is available though, environmental conditions are not the best due to high temperatures. França (2015) pointed out that geographical difficulties are aggravated by the individual's financial situation, since many pay for their own transportation and food.

Health care services should be restructured for the benefit of the SCD patients, and public policies should be adapted to the local culture to reduce the factors that affect vulnerabilities and life quality.

\section{Conclusions}

Despite the prognosis improvement of SCD patients because of a set of actions that have been implemented in the last years, there is still a long way to go in order to reduce their vulnerabilities. With regard to social vulnerability, municipality support is needed for transportation and food when treatment in another city is required. 
Individual vulnerability could be reduced by increasing the patients' knowledge of the disease and the trait through specific actions such as providing genetic information during family planning appointments, prenatal care, pediatric visits or Guthrie test. Moreover, the vaccine file of all SCD patients should be checked and information on the importance of special vaccines should be given as well as orientation on how to request them. Information on symptoms, strategies to avoid complications and appropriate diet are also required.

To reduce programmatic vulnerability active search and identification of people with the disease or the trait should be carried out in order to include them in the programs offered by the Family Health Units, and follow them up according to their needs. It is also necessary to offer and ensure the adequate supply of folic acid and explain to the patients its importance on the process of red blood cell production. Every SCD patient should have a specific number of appointments with specialists, according to the information gathered by the Family Health Unit and the patient's needs. When appointments are made outside the municipality, transportation should be ensured by a joint action of the Family Health Unit and the Transport Department of the municipality.

Beside the measures suggested above, it is important to foster the creation of a SCD patient association, where members could exchange experiences and talk about their problems and difficulties in order to find solutions and reduce vulnerabilities.

\section{Acknowledgment}

This study was financed in part by the Faculdade Maria Milza - FAMAM, Brazil, Finance Code 03.

\section{References}

Amaral, J. L. et al. (2015). Perfil sociodemográfico, econômico e de saúde de adultos com doença falciforme. Revista Rene, v. 16, n. 3, p. 296-305. https://doi.org/10.15253/2175$\underline{6783.2015000300002}$

Berardinelli, L. M. M. et al. (2010). Cronicidade e vulnerabilidade em saúde de grupos populacionais: implicações para o cuidado. Revista de Enfermagem, v. 18, n. 4, p. 553-558.

Braga, J. A. P. (2007). Medidas gerais no tratamento das doenças falciformes. Revista Brasileira 
de Hematologia e Hemoterapia, v. 29, n. 3, p. 233-238. https://doi.org/10.1590/S1516$\underline{84842007000300009 .}$

BRASIL. Departamento de Atenção Especializada, Secretaria de Atenção à Saúde, Ministério da Saúde. Manual de eventos agudos em doença falciforme. Brasília: Ministério da Saúde; 2009.

Departamento de Atenção Hospitalar e de Urgência, Secretaria de Atenção à Saúde, Ministério da Saúde. Doença falciforme: enfermagem nas urgências e emergências: a arte de cuidar. Brasília: Ministério da Saúde; 2014.

Ministério da Saúde. Anexo XXXVI da Portaria de Consolidação nº 02/GM/MS, de 27 de outubro de 2017, publicada no Diário Oficial da União no 190, de 03 de outubro de 2017, página 61, seção Suplemento DOU. Disponível em: http://portal.in.gov.br/

Ministério da saúde. Secretaria de atenção à saúde. Secretaria de ciência, tecnologia e insumos estratégicos. Portaria conjunta $\mathrm{n}^{\circ}$ 05, de 19 de fevereiro de 2018. Aprova o Protocolo Clínico e Diretrizes Terapêuticas da Doença Falciforme. Disponível em https://www.poderesaude.com.br/novosite/images/22.02.2018_III.pdf

Brignol, S. et al. (2015). Vulnerability in the context of HIV and syphilis infection in a population of men who have sex with men (MSM) in Salvador, Bahia State, Brazil. Cadernos de Saúde Pública, v. 31, n. 5, p. 1035-1048, 2015. https://doi.org/10.1590/0102-311X00178313

Chor, D.; Lima, C. R. A. (2005). Aspectos epidemiológicos das desigualdades raciais em saúde no Brasil. Cadernos de Saúde Pública, v. 21, n. 5, p. 1586-1594.

Cordeiro, R. C.; Ferreira, S. L.; Santos, A. C. C. (2014). Experiência do adoecimento de pessoas com anemia falciforme e estratégias de autocuidado. Acta Paulista de Enfermagem, v. 27, n. 6, p. 499-504. https://doi.org/10.1590/1982-0194201400082

Felix, A. A.; Souza, H. M.; Ribeiro, S. B. F. (2010). Aspectos epidemiológicos e sociais da doença falciforme. Revista Brasileira de Hematologia e Hemoterapia, v. 32, n. 3, p. 203-208. https://doi.org/10.1590/S1516-84842010005000072

Ferreira, S. L. et al. (2023). Vulnerability in adults with sickle cell disease: subsides for nursing care. Ciência Cuidado e Saúde, v. 12, n 4, p.711-718. https://doi.org/10.4025/cienccuidsaude.v12i4.18723

FRANÇA, S. B. A. Fatores que interferem no acesso de pessoas com doença Falciforme ao hemocentro coordenador da Bahia. [Dissertação]. Salvador (BA): Universidade Federal da Bahia; 2015.

Frauches, D. O. et al. (2010). Vacinação contra pneumococo em crianças com doença falciforme no Espírito Santo entre 2004 e 2007. Epidemiologia e Serviços de Saúde, v. 19, n. 2, p. 165172. https://doi.org/10.5123/S1679-49742010000200009 
Gomes, L. M. X. et al. (2014). Access and care of individuals with sickle cell anemia in a primary care service. Acta Paulista de Enfermagem, v. 27, n. 4, p. 348-355. https://doi.org/10.1590/1982-0194201400058

Guimarães, C. T. L. \& Coelho, G. O. (2010). A importância do aconselhamento genético na anemia falciforme. Ciência \& Saúde Coletiva, v. 15, p.1733-1740. https://doi.org/10.1590/S1413-81232010000700085

Jesus, J. A. (2010). Doença Falciforme no Brasil. Gazeta Médica da Bahia, v. 80, n. 3, p. 8-9.

Martins, P. R. J.; Souza, H.; Silveira, T. B. (2010). Morbimortalidade em doença falciforme. Revista Brasileira de Hematologia e Hemoterapia, v. 32, n. 5, p. 378-383. https://doi.org/10.1590/S1516-8484201000050001

Oakis, L. L.; Bento, A. C. G.; Silva, N. A. (2023). Anemia falciforme: os malefícios ocasionados pela anemia falciforme em indivíduos homozigóticos. Revista Fiar: Revista do Núcleo de Pesquisa e Extensão, v. 2, n. 1, p. 149-171.

Ohara, D. G. et al. (2012). Dor osteomuscular, perfil e qualidade de vida de indivíduos com doença falciforme. Brazilian Journal of Physical Therapy, v. 16, n. 5, p. 431-438. https://doi.org/10.1590/S1413-35552012005000043

PITALUGA, W. V. C. Avaliação da qualidade de vida de portadores de anemia falciforme. [Dissertação]. Goiânia (GO): Universidade Católica de Goiás; 2006.

Roberti, M. D. R. F. et al. (2010). Avaliação da qualidade de vida em portadores de doença falciforme do Hospital das Clínicas de Goiás, Brasil. Revista Brasileira de Hematologia e Hemoterapia, v. 32, n. 6, p. 449-454. https://doi.org/10.1590/S1516-84842010000600008

Santos, E. C.; Koller, S. H.; Pereira, M. T. L. N. (2004). Religião, Saúde e Cura: um Estudo entre Neopentecostais. Psicologia ciência e profissão, v. 23, n. 3, p. 82-91.

Silva, A. K. L. S.; Silva, H. P. (2013). Anemia falciforme como experiência: relações entre vulnerabilidade social e corpo doente enquanto fenômeno biocultural no estado do Pará. Amazônica. Revista de Antropologia da Universidade Federal do Pará, v. 5, n. 1, p. 10-36. https://doi.org/10.18542/amazonica.v5i1.1295

Silva, H. D. et al. (2013). Anemia falciforme e seus aspectos psicossociais: o olhar do doente e do cuidador familiar. Revista Cuidarte, v. 4, n. 1, p. 475-83.

Zago, M. A.; Pinto, A. C. S. (2007). Fisiopatologia das doenças falciformes: da mutação genética à insuficiência de múltiplos órgãos. Revista Brasileira de Hematologia e Hemoterapia, v. 29, n. 3, p. 207-214. https://doi.org/10.1590/S1516-84842007000300003 